\title{
A remote sensing and GIS based application for monitoring water levels at Kariba dam.
}

\author{
Adonia Shumba ${ }^{1}$, Webster Gumindoga ${ }^{2}$, Sydney Togarepi ${ }^{3}$,Tarirai Pinias Masarira ${ }^{4}$ Edward \\ Chikuni $^{5}$ \\ \{adoniashumba@yahoo.com¹,wgumindoga@mail.com² stogarepi@gmail.com³ \\ University of Zimbabwe \\ Department of Geoinformatic and Surveying ${ }^{1}$, \\ University of Zimbabwe \\ Department of Electrical Engineering ${ }^{2}$
}

\begin{abstract}
The Global warming effect has had negative impacts on water resources in Zimbabwe due to erratic rainfall patterns. The overall effect leads to reduction in power generation on hydropower stations as a result of low water levels. Water level monitoring at hydro power generation reservoirs is thus of utmost importance. Currently employed in situ based water level monitoring techniques are less efficient and do not provide the synoptic coverage of the lake. We present the relationship between factors (natural and anthropogenic) affecting water levels and the measured water levels. The factors were derived from remote sensed data. To ascertain the most significant factors contributing to water level and electricity generation fluctuations, correlation and regression were used. The regression models generated were used to design an application. The application automated the processing satellite imagery. From the automated extraction of rainfall data and land use/cover classification water level monitoring was achieved.
\end{abstract}

Keywords: Water level monitoring, Kariba dam, Remote sensing and GIS tool

ACRID 2017, June 20-21, Victoria Falls, Zimbabwe

Copyright (C) 2017

DOI 10.4108/eai.20-6-2017.2270774 


\section{Introduction}

Kariba dam is one of the largest manmade dams in the world located in the southern hemisphere between Zimbabwe and Zambia. It was constructed along the Zambezi River from 1955 to 1959 and has a storage capacity of $180 \mathrm{~km} 3$. The dam extends over a length of $300 \mathrm{~km}$ and a surface area of $5500 \mathrm{~km} 2$ at full capacity (Kunz, 2011). Water stored in dams is a backbone for the agriculture, hydropower and recreational sectors of the economy. The main purpose for the construction of the Kariba dam was for hydroelectric power generation for both Zambia and Zimbabwe. Besides having a viable fishing and tourism industry, the dam contributes about $55 \%$ of the Zimbabwe's electric power supply when running at full capacity and supplies a sum total of 1830 MW for both Zimbabwe and Zambia (Mhlanga and Nyikahadzoi, 2013).

The major agent to hinder current and futuristic power generation at full capacity in the Zambezi basin is drought. Drought tends to reduce surface runoff and thus reduce storage volumes in reservoirs resulting in a reduction in energy generation potential (Yamba et al., 2011). Besides rainfall, human alteration of the natural ecosystem inform of deforestation, improper farming activities affect the natural inflows into the lakes.

The consequences of the water level decreases have recently been significantly felt during the 2014/15 season. In Zimbabwe load shedding of a maximum of 10 hours per day were experienced particularly in urban centres like Harare and Bulawayo and their dormitory towns. The Zambezi River Authority cited low rainfall experienced during the previous rainy season as the reason for the load shedding crisis. The decreases in water levels have initiated the decreases in the power generation capacity throughout Zimbabwe from $750 \mathrm{MW}$ to $475 \mathrm{MW}$. The Kariba dam was designed as a multi-year water storage resource implying that a sole rainy season cannot be enough to fill up the dam and as such a single drought must not significantly influence the power generation. Low inflows alone cannot contribute to low water levels currently being experienced.

The existing water level monitoring techniques fail to account for varying changes in the water levels as a result of the unpredictable global warming and Elnino effects. Some of the monitoring techniques in use nowadays include Catchment Water balance and tide gauges. All these methods have limitations in that they are limited in spatial extent resulting in the inability to take measurements on inaccessible sites. They also fail to determine and measure the dynamic variables which affect water levels like rainfall, evaporation and siltation levels.

There is urgent need to device other efficient and effective spatial and temporal water level monitoring techniques that monitor not only the levels but land cover changes, changing rainfall patterns and evapotranspiration patterns upstream of the dam and within the basin. Remote sensing and GIS techniques provide the perfect platform for a full package monitoring system. An improved understanding of how the changes in dam water levels are being related to changes in the surrounding climatic and anthropogenic factors must constantly be analysed. The effect of these changes should be related to the power generation quantities so that proper decisions can be made to effectively generate power. There is need to monitor all the upstream 
activities (both natural and anthropogenic) and relate them to the decrease in levels and thus provide sufficient information to all stakeholders. 


\section{Materials and Methods}

\subsection{Study area}

The Zambezi river basin is the fourth largest and most sensitive basin in Africa and the largest in the Southern Africa. The total surface area covered by the basin is 1.37 million $\mathrm{km} 2$ and it generally extends across eight nations namely Angola, Malawi, Tanzania, Mozambique Zambia, Namibia, Botswana and Zimbabwe (Macdonald, 2007). It is subdivided into the upper, middle and lower Zambezi basin with the upper basin being found upstream of the Victoria Falls, middle being located between Victoria Falls and the Cabora Bassa falls and the lower part found down stream of Cabora Bassa. The dominant soil type is the sandy Kalahari soils which are easily eroded. The portion of the area covered by Lake Kariba basically records a mean annual rainfall of about $600 \mathrm{~mm}$ (Magadza, 2006). The main land use function in the catchment area is subsistence farming and pastoralism. The major tributary rivers which drain into Lake Kariba are Gwayi, Sengwa and Sanyati rivers. The major inflow sources into the Zambezi River are mainly from the Kafue, Luangwa and Shire sub basin tributaries. A minor $10 \%$ of the mean annual rainfall within the basin contributes to the flow of the Zambezi River (Phiri, 2011). Figure 1 shows the study area.

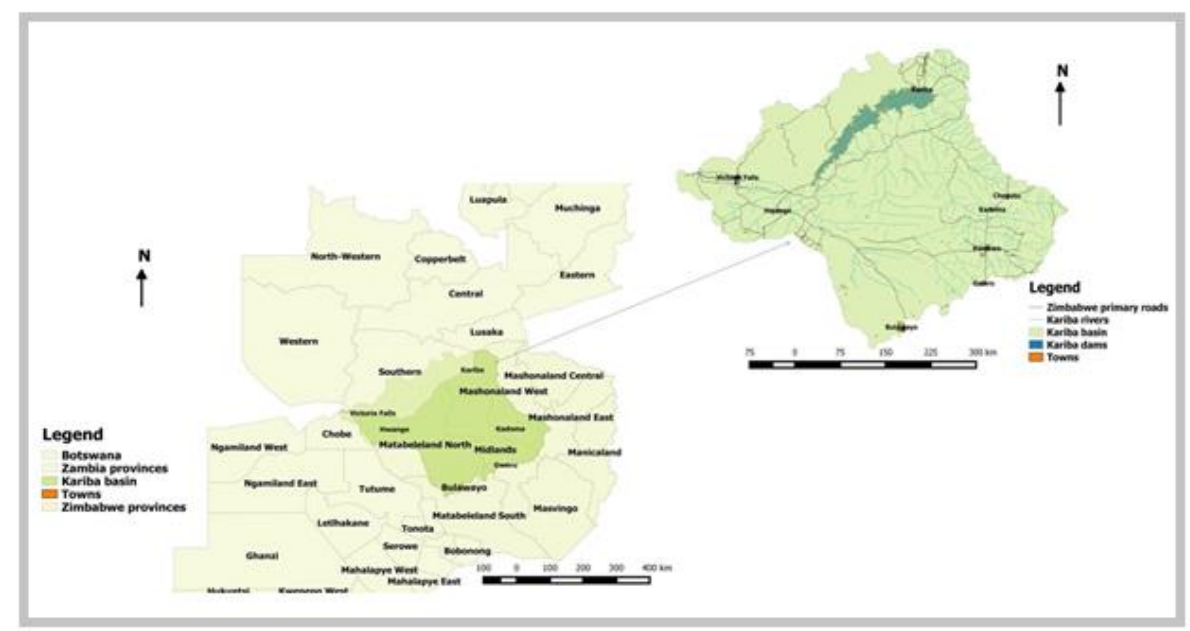

Fig. 1 Map of study area (first: Kariba basin in Zimbabwe and Zambia, second: Lake Kariba in Kariba basin) 


\subsection{Data Availability}

The imagery used in this study is Landsat 1 (MSS), 5 (TM and MSS) and Moderate Resolution Imaging Spectro-radiometer (MODIS) with a cloud cover of less than 10\%. Landsat imagery was acquired from the Glovis website from August 1973 to August 1998. The images were acquired for 10 year intervals so as to observe significant land cover changes. MODIS imagery was acquired from the Eodis website between the periods of August 2005 to August 2015. All the images were acquired during the dry season in Zimbabwe i.e. from May to October to enable minimum cloud cover images to be obtained. Table 1 indicates the detailed information on the imagery acquired for the project.

Table 1. Landsat and MODIS imagery used for land cover/use classification

\begin{tabular}{lllll}
\hline Year & Month & Mission & Spatial resolution & Bands Combination used \\
\hline 1973 & August & Landsat 1(MSS) & $60 * 60$ & 6 (Near IR), 5 (Red), 4 (Green) \\
1984 & August & Landsat 5(MSS) & $60 * 60$ & 2 (Green), 3 (red), 1 (Blue) \\
1998 & August & Landsat 5 (TM) & $30 * 30$ & 5 (Mid IR), 4 (Near IR), 3 (Red) \\
2005 & August & MODIS terra NDVI & $250 * 250$ & $1($ Red), 2(Near IR) \\
2010 & August & MODIS terra NDVI & $250 * 250$ & $1($ Red), 2(Near IR) \\
2015 & August & MODIS terra NDVI & $250 * 250$ & $1(\mathrm{Red}), 2($ Near IR)
\end{tabular}




\subsection{Image pre-processing and classification}

The first stage in the pre-processing stage involved the use of the open access Integrated Land and Water Information System (ILWIS) software to import the downloaded geo tiff Landsat imagery. The next step involved gluing of the tiles and for this study, 10 tiles were glued together covering the whole basin. After gluing of the tiles, a map list was created for Landsat 1 using band combinations of 6, 5, and 4 . For Landsat 5 (MSS) band combinations of bands 2, 3 and 1 were used. The map list for Landsat5 (TM) was made using band combinations 5, 4 and 3. From the map lists created sample sets constituting of land use/ cover classes namely forest and shrubs, grassland, bare land, cultivated land, open water and settlements. To enable supervised classification the next stage involved use of the maximum likelihood function to classify the images. Using the shapefile which defined the hydrological boundary, the cross function was used to clip the classified tiles to come out with the final resulting output.

Classification of MODIS imagery was carried out using the (Normalized Differencing Vegetation Index) NDVI calculation operation in ILWIS for the 2005, 2010, 2015 satellite images. The next step involved making use of the "slicing" operation to classify the image using the same classes used in Landsat. From the sliced imagery, the "cross" operation was then used to clip the Zambezi basin from the sliced image using the boundary shape file.

\subsubsection{Extraction of rainfall data from Climatic Hazards Group Infrared Precipitation with Stations (CHIRPS)}

Monthly rainfall imagery of CHIRPS from 1981 to 2014 was downloaded from the USGS website. The images were exported in ILWIS before using the "cross" operation to extract rainfall data for the Kariba basin. The table histogram operation was then applied on each and every monthly rainfall data set to get the average rainfall across the whole basin. Rainfall data from CHIRPS imagery was validated with rainfall measured in-situ data obtained at the Kariba airport Meteorological Station. By taking advantage of the average monthly data across the basin from the imagery, simple comparison was made to in-situ data 


\subsubsection{Automating Land classification and retrieval of rainfall data}

The automation of all ILWIS operations leading to the classification of imagery was carried out using the Vb.net application programmed in Microsoft visual studio platform. Due to the ability of ILWIS to act as a (Data Dynamic Exchange) DDE server, ILWIS scripting commands were retrieved and accessed using the "vb.net" client shelling operation. The program was designed in such a way that all satellite image processing could be done by any user who may be illiterate in Remote sensing and ILWIS. The application required the user to firstly specify the year and month of the imagery from the drop down combo boxes. Selecting of the required imagery and clicking the Execute classification button would trigger the ILWIS commands to automatically process the selected image. 


\title{
3 Results and Discussion
}

\author{
3.1 Land use change trends (1973-2015)
}

Figure 2. shows thematic maps for land cover changes in the Kariba basin and Table 2 shows the area coverage changes in land cover classes identified in the dry season i.e. Water, Bare-land, Cultivation, Settlements, Grassland and Forest and Shrubs.

Table 2 shows that cultivation generally increased gradually from 1984 to 1998 by about $34 \%$ and decreased by $2 \%$ from 2005 to 2010 . Bare-land area value increased from 1973 to 1998 by about $8 \%$. The largest areas recorded for bare-land area are from the years 1998, 2010 and 2015. Grassland occupied areas decreased from 1973 to 2005 by an average of $7 \%$. 1998 recorded the least area covered by grassland. A significant reduction in \% area covered by grassland is noticeable from 2005 to 2010 i.e. from $71 \%$ to $54 \%$.

In general, a decreasing trend constitutes the area covered by forest and shrubs from 1984 to 2015 . A sharp decrease in forest area of about $20 \%$ is noticed between 1984 and 1998. From 2005 to 2015 there is a significant gradual decrease in area covered by forest and shrubs of about $19 \%$. The area for settlement is generally escalating in value from 1973 to 2015 with a minimum value noted between 1973 and 1984 and a highest value in 1998. The area occupied by open water from 1973 to 2015 shows a small gradual decrease. 1973 and 1998 recorded the highest water area coverage. From 2005 to 2010 there is a gradual decrease in area of average $6 \mathrm{~km} 2$.

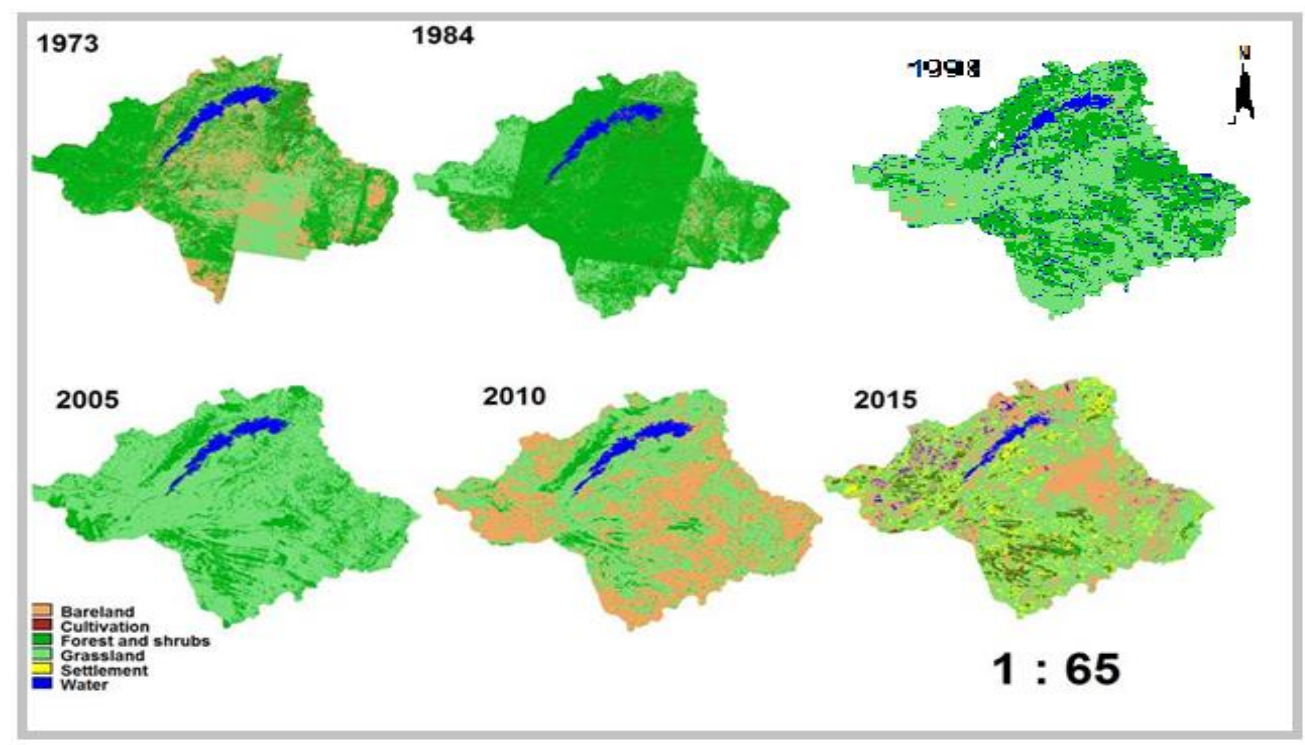

Fig.2: Land use change trends (1973-2015) 
Beilfuss (2000) who investigated the major land use changes in the Zambezi catchment highlighted between 1960 to 199 cited that forests within the basin had reduced by $4.9 \%$. The research also noted a $25 \%$ increase in hyphaene palms cover on previously bare-land in the southern part of the Zambezi delta and a reduction in area occupied by open surface water.

Table 2. Land use area changes in Kariba catchment (1973-2015)

\begin{tabular}{|c|c|c|c|c|c|c|c|c|c|c|c|c|}
\hline Land use & $\begin{array}{l}\text { Area } \\
\left(\mathrm{km}^{2}\right)\end{array}$ & $\begin{array}{l}\text { Area } \\
\%\end{array}$ & $\begin{array}{l}\text { Area } \\
\left(\mathrm{km}^{2}\right)\end{array}$ & $\begin{array}{l}\text { Area } \\
\%\end{array}$ & $\begin{array}{l}\text { Area } \\
\left(\mathrm{km}^{2}\right)\end{array}$ & $\begin{array}{l}\text { Area } \\
\%\end{array}$ & $\begin{array}{l}\text { Area } \\
\left(\mathrm{km}^{2}\right)\end{array}$ & $\begin{array}{l}\text { Area } \\
\%\end{array}$ & $\begin{array}{l}\text { Area } \\
\left(\mathrm{km}^{2}\right)\end{array}$ & $\begin{array}{l}\text { Area } \\
\%\end{array}$ & $\begin{array}{l}\text { Area } \\
\left(\mathrm{km}^{2}\right)\end{array}$ & $\begin{array}{l}\text { Area } \\
\%\end{array}$ \\
\hline & 1973 & 1973 & 1984 & 1984 & 1998 & 1998 & 2005 & 2005 & 2010 & 2010 & 2015 & 2015 \\
\hline Cultivation & 4461 & 3 & 2127.7 & 1 & 57008.5 & 35 & 356.8 & 2 & 245.9 & 0 & 7233.5 & 5 \\
\hline Bare-land & 30879 & 20 & 6028.6 & 4 & 51523.8 & 31 & 126.9 & 1 & 57885.6 & 36 & 42075.3 & 29 \\
\hline Forest \& shrubs & 73802 & 47 & 119818 & 72 & 29900.9 & 18 & 41116.1 & 25 & 9774.4 & 6 & 8864.3 & 6 \\
\hline Grassland & 42453 & 27 & 31804.0 & 19 & 19262 & 12 & 117354 & 71 & 86659.6 & 54 & 79528.7 & 56 \\
\hline Open-water & 4957 & 3 & 4553.0 & 3 & 4972.9 & 3 & 4307,0 & 2.6 & 4301.4 & 2.6 & 4654.5 & 3 \\
\hline Settlement & 120,5 & 0 & 148.375 & 0 & 2119.0 & 1 & 264.75 & 1 & 466.1 & 0.2 & 211.717 & 0.1 \\
\hline
\end{tabular}

The Zambezi River Authority (2014) highlighted the rise in forest fires, deforestation, and clearing of land for cultivation has significantly resulted in immense clearing of woodlands into open shrub land on peripheries of Siavonga and Chirundu towns.

Taimu (2014) reported a wide spread reduction in flooded and open water areas between 1977 and 1990 and a widespread of woodland expansion into the 
floodplain from 1979 to 1990 . The largest decrease was noticed between 1986 and 1994. Grasslands monitored also showed an increase from 1986 to 1994 and a decrease in 1994 and 2008. The author cited the changes in grassland as due to conversion of grassland into other land cover types. The reduction in forest cover may be attributed to the clearing of land for cultivation, settlement since these land uses seem to be negatively correlated with the forest cover.

Table 3. Classification accuracy assessment results

\begin{tabular}{|c|c|c|c|c|c|c|c|c|}
\hline & Classificatio & esults & & & & & & \\
\hline & Cultivation & Bareland & $\begin{array}{l}\text { Forest } \\
\text { shrubs }\end{array}$ & $\&$ & Open water & Grassland & Settlement & Acc \\
\hline Cultivation & 20 & 4 & 0 & & 0 & 1 & 6 & 0.64 \\
\hline Bareland & 5 & 10 & 0 & & 0 & 2 & 4 & 0.48 \\
\hline Forest \&shrubs & 0 & 0 & 30 & & 0 & 2 & 0 & 0.94 \\
\hline Open water & 0 & 0 & 0 & & 31 & 3 & 0 & 0.91 \\
\hline Grassland & 2 & 0 & 3 & & 0 & 15 & 0 & 0.75 \\
\hline Settlement & 4 & 1 & 0 & & 0 & 0 & 5 & 0.5 \\
\hline Reliability & 0.64 & 0.66 & 0.9 & & 1.00 & 0.6 & 0.3 & \\
\hline Average accuracy & $70 \%$ & & & & & & & \\
\hline \multicolumn{9}{|l|}{ Average } \\
\hline reliability & $68 \%$ & & & & & & & \\
\hline
\end{tabular}




\subsection{Change in land cover types in relation to water-levels at Kariba dam.}

From Table 4 the correlation between annual water level and land cover variables the correlation coefficient for water area with relation to water levels is 0.27 implying that a weak negative correlation exists between water area and water levels. The R2 value of 0.04 indicates $4 \%$ variation of water levels are explained by water area. Thus, changes in water area insignificantly affect the water levels. The correlation coefficient for forest and shrubs and water levels is -0.78 highlights a strong negative dependency between the two variables. The $p$ value of 0.02 is less than 0.05 , thus the relationship is statistically significant. A decrease in forest and shrubs area contributes $13 \%$ of the increase in water level. The correlation coefficient for grassland is 0.54 highlights a fairly strong positive dependency between grassland area and water level. The change in grassland area contributes $10 \%$ of the variation in water level. The p value of 0.04 is less than 0.05 , thus the relationship is statistically significant.

The correlation coefficient for cultivated area is -0.24 highlights a weak negative correlation between the two variables. An increase in cultivated area contributes $3 \%$ of the reduction in water level. The p value of 0.697 is greater than 0.05 and thus the relationship is not statistically significant. The correlation coefficient bareland is -0.16 highlights a fairly weak negative correlation coefficient between the two variables. The Bare-land area contributes $2 \%$ of the decrease in water level. The correlation coefficient for settlement area is -0.11 highlights a relatively weak negative correlation coefficient between the two variables. The settlement area contributes $1 \%$ of the variation in water level. From the $\mathrm{p}$ values forest cover and grassland have values less than 0.05 implying that their correlation with water level is statistically significant. The other variables have insignificant correlation to water levels. 
Table 4. Change in land cover types in relation to water-level

\begin{tabular}{lllll}
\hline $\begin{array}{l}\text { Dependent } \\
\text { variable }\end{array}$ & Independent variable & $\mathrm{r}$ & $\mathrm{R}^{2}$ & $\mathrm{P}$ value \\
\hline Annual average & Water area $\left(\mathrm{km}^{2}\right)$ & -0.276 & 0.04 & 0.653 \\
water-level $(\mathrm{m})$ & Forest and shrubs $\left(\mathrm{km}^{2}\right)$ & -0.78 & 0.13 & 0.02 \\
& Grassland $\left(\mathrm{km}^{2}\right)$ & 0.54 & 0.10 & 0.04 \\
& Cultivated $\operatorname{area}\left(\mathrm{km}^{2}\right)$ & -0.24 & 0.03 & 0.697 \\
& Bare land $\left(\mathrm{km}^{2}\right)$ & -0.164 & 0.02 & 0.79 \\
& Settlement $\left(\mathrm{km}^{2}\right)$ & -0.110 & 0.012 & 0.86 \\
\hline
\end{tabular}

The National Academy of Sciences of the United States of America (2008) cited that the removal of forest cover tends to speed up the rate of conversion of precipitation to inflows. Deforestation thus results in temporary rise in reservoir water levels. An increase in the rate of conversion rate of rainfall to inflows implies that water levels will increase thus the result tallies with the negative correlation between change in forest cover and water level obtained in this study. Legesse et al (2003) however highlighted that up to $8 \%$ increase in inflows into Lake Zeway could be expected if the grassland were to be converted to other land uses like cultivation. It is thus evident that as the grassland area decrease, the inflow volumes and water levels would increase. Mbano et al. (2009) also noted that forest cover increase in the Zambezi basin from 1950 to 2000 had resulted in water flow reduction into the water reservoirs. According to the same report, increase in settlement area had an insignificant effect on the water resources.

From the standard linear regression model

$$
a+b * x=y
$$

Whereby; $\mathrm{a}=\mathrm{y}$ intercept (constant)

$$
\mathrm{b}=\text { slope }
$$

$\mathrm{y}=$ dependent variable (annual average water level $(\mathrm{m})$ in our case) and $\mathrm{x}$ is the independent variable

Table 5. Change in land cover types in relation to water level 


\begin{tabular}{|c|c|c|c|}
\hline Water surface & -0.002 & -0.5 & 0.65 \\
\hline $\operatorname{area}\left(\mathrm{km}^{2}\right)$ & 491.702 & 26.74 & 0.0 \\
\hline \multicolumn{4}{|l|}{ Constant (a) } \\
\hline Forest & -0.0004 & -2.134 & 0.02 \\
\hline$\& \operatorname{shrubs}\left(\mathrm{km}^{2}\right)$ & 484.931 & 356.64 & 0.0 \\
\hline \multicolumn{4}{|l|}{ Constant (a) } \\
\hline Grassland $\left(\mathrm{km}^{2}\right)$ & 0.00003 & 1.11 & 0.04 \\
\hline Constant (a) & 482.86 & 244.2 & \\
\hline Cultivated & -0.0002 & -0.43 & 0.697 \\
\hline $\operatorname{area}\left(\mathrm{km}^{2}\right)$ & 482.87 & 350.05 & 0 \\
\hline \multicolumn{4}{|l|}{ Constant (a) } \\
\hline Bare-land & -0.00002 & -0.164 & 0.79 \\
\hline $\operatorname{area}\left(\mathrm{km}^{2}\right)$ & 482.806 & 332.57 & 0.0 \\
\hline \multicolumn{4}{|l|}{ Constant (a) } \\
\hline Settlement & 0.0005 & -0.19 & 0.86 \\
\hline $\operatorname{area}\left(\mathrm{km}^{2}\right)$ & 482.768 & 305.01 & 0.00 \\
\hline Constant (a) & & & \\
\hline
\end{tabular}

annual average water level $=-0.002($ water area $)+491.702$

annual average water level $=-0.0004$ (Forest and Shrubs) +484.931

annual average water level $=0.00003$ (Grassland area $)+480.72$

annual average water level $=-0.0002$ (Cultivated area) +482.873

annual average water level $=-0.00002$ (Bareland area) +482.806

annual average water level $=0.0005$ (Settlement area $)+482.768$

\subsection{Change in climatic and environmental factors in relation to water-level and electricity generated at Kariba dam.}

From Table 6, the correlation coefficient between annual average water level and annual total rainfall which is 0.70 indicates a strong positive correlation between the two variables. The $p$ value of 0.022 (which is less than 0.05 ) implies that rainfall is a significant contributing factor to variation in water level. About $63 \%$ of the variation in water level is explained by rainfall. When outflows are related to water level, a weak positive correlation factor of 0.13 is noticed. A p value of 0.08 (which is greater than 0.05 ) between outflows and water levels highlights that the magnitude of outflows is not a contributing factor to variation in water level. About $7 \%$ of the variation in water level is explained by the mean turbine and spillway discharges.

The correlation coefficient between water level and total annual evaporation i.e.0.53 indicates a strong negative dependency between the two variables. $15 \%$ of the reduction in water-level is explained by losses due to evaporation. The $p$ value of 0.00 is less than 0.05 thus the relationship is statistically significant. For the inflow the most significant correlation value is explained by the Kalomo water levels with a strong positive correlation of 0.859 . Its corresponding $\mathrm{p}$ value of 0.343 is however 
greater than 0.05 implying that the correlation is not statistically significant. $73 \%$ of the variation in water dam levels in Kariba dam is explained by the Kalomo inflow water levels. Sanyati inflows, Sanyati water levels, Zambezi River flow rate and Gwayi water levels have weak positive correlation factors of $0.177,0.207,0.257$ and 0.029 respectively. The correlation coefficient of 0.387 between the mean annual electricity generated and annual average water level is a weak positive correlation factor. $15 \%$ of the variation in annual electricity generated is explained by the annual water level at Kariba dam.

Unganai (1996) conducted a rainfall trend analysis from 1900 to 1994 on the Zambezi basin and discovered that annual rainfall had decreased by about $10 \%$ resulting in lowering of water levels in reservoirs. The years which experienced significant drought for example the year 1992 had very low reservoir volumes. Arnell (1999) also observed a reduction in surface water runoff of about $30 \%$ in the Zambezi basin as a result of reduced rainfall and increased evaporation.

Yamba et al. (2011) investigated the environmental factors which affect hydro power generation at Kariba dam and found out rainfall and inflow water levels to be the primary significant factors which explained the variation in power generated. The writer noted that as the rainfall and inflow volumes increased the quantity of power generated also increased. Beilfuss (2012) cited that $11 \%$ the river inflows into Kariba dam are lost through evaporation and these losses accelerate the possibility of shortfalls in generation of power. The results noted from the authors above concur with observations made in this study in that rainfall, evapotranspiration and inflows are the significant factors contributing to water level variations.

Table 6. Change in environmental and anthropogenic factors in relation to water-level and electricity generated at Kariba dam (1960-2011)

\begin{tabular}{|c|c|c|c|c|}
\hline Dependent variable & Independent variable & $\mathrm{r}$ & $\mathrm{R}^{2}$ & $\mathrm{P}$ value \\
\hline \multirow[t]{3}{*}{ Annual average water-level (m) } & Annual total rainfall $(\mathrm{mm})$ & 0.70 & 0.63 & 0.022 \\
\hline & $\begin{array}{l}\text { total annual mean turbine and } \\
\text { spillway discharges }\left(\mathrm{m}^{3} / \mathrm{s}\right)\end{array}$ & 0.13 & 0.07 & 0.08 \\
\hline & total annual evaporation(mm) & -0.53 & 0.28 & 0.00 \\
\hline
\end{tabular}




\begin{tabular}{l|llll} 
& inflow volumes: & & \\
Kalomo water levels $(\mathrm{m})$ & 0.859 & 0.737 & 0.343 \\
Sanyati inflows $\left(\mathrm{m}^{3} / \mathrm{s}\right)$ & 0.177 & 0.03 & 0.529 \\
Sanyati water levels $(\mathrm{m})$ & 0.207 & 0.043 & 0.441 \\
Mean & Zambezi river flowrate $\left(\mathrm{m}^{3} / \mathrm{s}\right)$ & 0.257 & 0.066 & 0.072 \\
generated(MWH) & Gwayi water levels $(\mathrm{m})$ & 0.029 & 0.001 & 0.928 \\
& & & 0.15 & 0.04 \\
Annual average water level $(\mathrm{m})$ & 0.56 & 0.20 & 0.03 \\
Annual total rainfall $(\mathrm{mm})$ & 0.6 & 0.10 & 0.01
\end{tabular}

From the standard linear regression model

$$
y=a+b * x
$$

Whereby; $\mathrm{a}=\mathrm{y}$ intercept (constant)

$$
\mathrm{b}=\text { slope }
$$$$
\mathrm{y}=\text { dependent variable (annual average water level }(\mathrm{m}) \text { in our case) }
$$
and $\mathrm{x}$ is the independent variable (annual total rainfall $(\mathrm{mm})$ )

Table 7. Change in environmental and anthropogenic factors in relation to water-level and electricity generated at Kariba dam (1960-2011) (Regression analysis) 


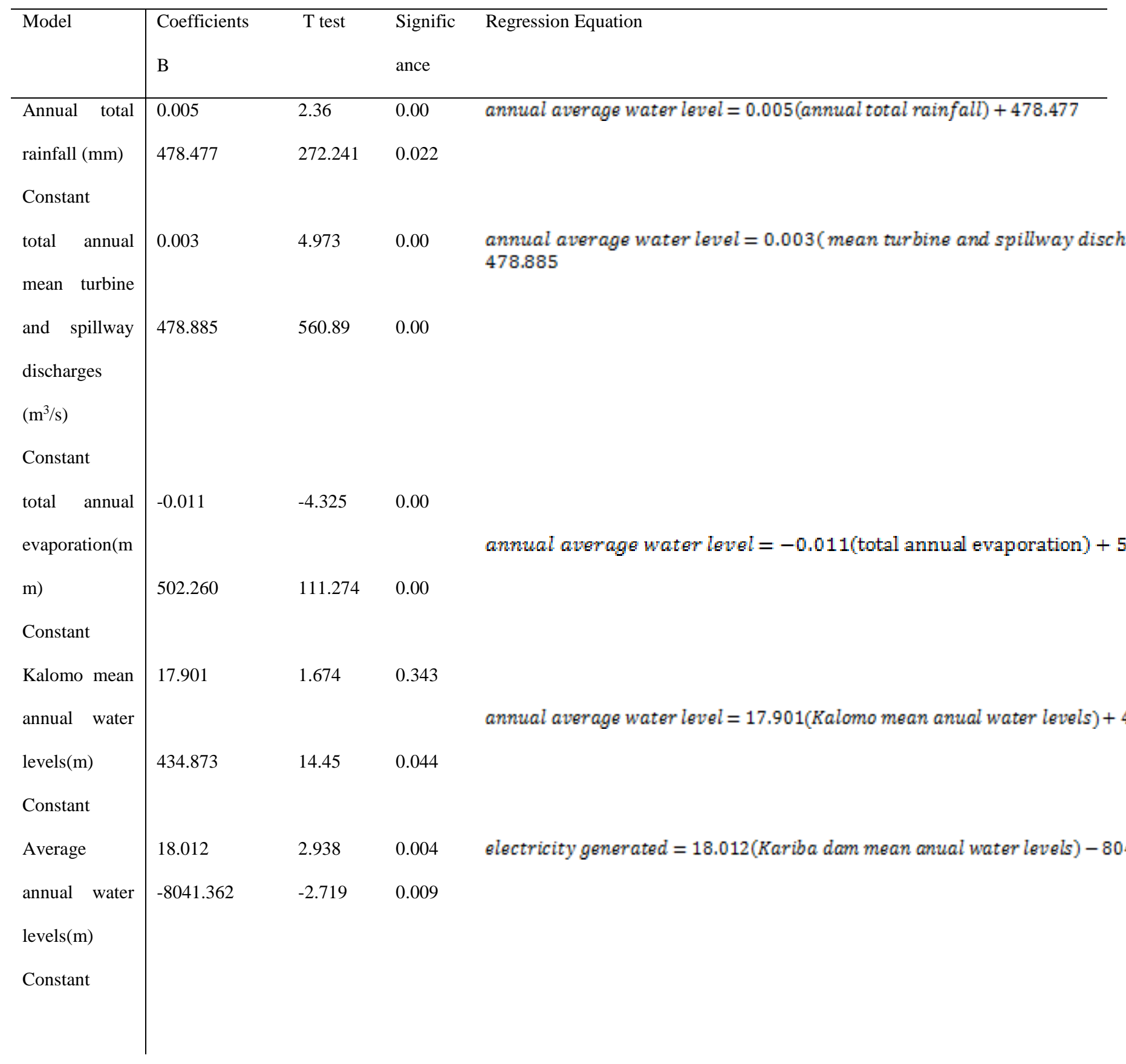

3.4 Rainfall change trends (1982-2014) 
Rainfall data for the Kariba basin obtained from CHIRPS imagery in Figure 3. highlights that 1982 and 1992 had the least amount of rainfall. The years 2000 and 2005 experienced the highest maximum rainfall of average $1122.475 \mathrm{~mm} .1992 \mathrm{had}$ the least amount of rainfall with a maximum value of just about $666.47 \mathrm{~mm}$.

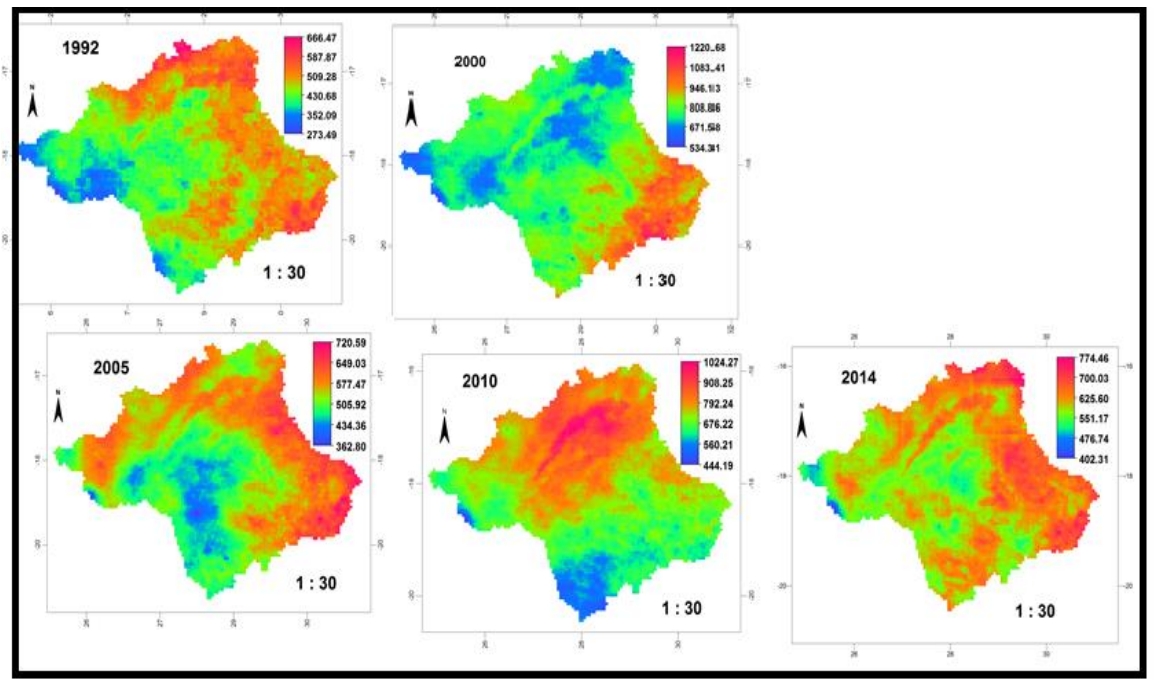

Fig. 3: Annual total rainfall in Kariba basin (1992-2014)

\subsubsection{Change in inter-annual rainfall (from CHIRPS) in relation to Kariba dam water levels and electricity generated}

A strong positive correlation factor of 0.75 in Table 8 between water levels and rainfall data implies that rainfall is a major contributing factor to water level decreases or increases. $75 \%$ of the variation in water levels is explained by satellite rainfall data. The $\mathrm{p}$ value of 0.025 is less than 0.05 and thus the relationship between the two variables is statistically significant. A strong positive correlation factor of 0.6 exists between annual rainfall and annual electricity generated. $80 \%$ of the variation in electricity is thus explained by annual rainfall. A p value (0.01) is less than 0.05 thus the relationship is statistically significant.

Table 8. Change in inter-annual rainfall in relation to Kariba dam water level and electricity generated (1981-2014) 


\begin{tabular}{lllllll}
\hline Dependent variable & \multicolumn{2}{l}{ Independent variable } & $\mathrm{r}$ & $\mathrm{R}^{2}$ & $\mathrm{P}$ value \\
\hline Annual average & Total annual rainfall from & 0.8 & 0.75 & 0.025 \\
water level (m) & CHIRPS (mm) & & & & \\
Mean annual & & & & & & \\
electricity & & & & & & \\
generated(MWH)
\end{tabular}

The linear equations showing the variation in rainfall with water levels and electricity generated are highlighted in Table 9

Table 9. Change in inter-annual rainfall in relation to Kariba dam water level and electricity generated (1981-2014)

\begin{tabular}{l|llll}
\hline Model & Unstandardized & T & Signific & Regression Equation \\
& coefficients & test & ance & \\
& B & & & \\
\hline Annual & 0.011 & 2.44 & 0.00 & annual average water level $=0.011$ (annual total rainfall) +475.619 \\
total rainfall & 475.619 & 164.9 & 0.025 & \\
(mm) & & 7 & & \\
Constant & & & &
\end{tabular}

\subsection{Usage of the Application}

The desktop application allows water resource managers to monitor not only the water levels but the variables affecting water levels i.e. rainfall, evaporation and Land use/cover changes within the whole basin. The automation process of water level monitoring is done by the automatic downloading and processing of the satellite imagery. From the satellite imagery which captures all the variables which affect levels such as rainfall and evaporation, corresponding water level values will thus be derived by the application. 
Land use and land cover changes within the Zambezi basin can be monitored and based on the magnitude of their change, corresponding water level values are derived. The output land cover maps are saved on a predefined folder and can be displayed on the map window on request by the user.

Rainfall and evaporation satellite data provide the near real time monitoring capabilities of water levels. From the application extraction of satellite rainfall and evaporation data can be carried out within the click of a button and corresponding accurate water level values be derived. Rainfall output maps can be displayed on the map window. Based on the derived rainfall, evaporation and land use and cover changes, effective and sustainable planning decisions can be implemented to enable the effective generation of electricity. Proper decision making based on the changes in demand of electricity can be initiated. By making use of satellite datasets the complete synoptic coverage of the land use/cover activities, rainfall and evaporation dynamics within the basin will always be continuously monitored. The major advantage of CHIRPS rainfall datasets are that they already have in-situ station data embedded on them thus eliminating the need to acquire rainfall data from the meteorological offices. Fig 4 highlights how the change in land cover/ use has resulted in the lowering of water levels to $481.72 \mathrm{~m}$. The map window indicates the tributary rivers into the Lake Kariba.

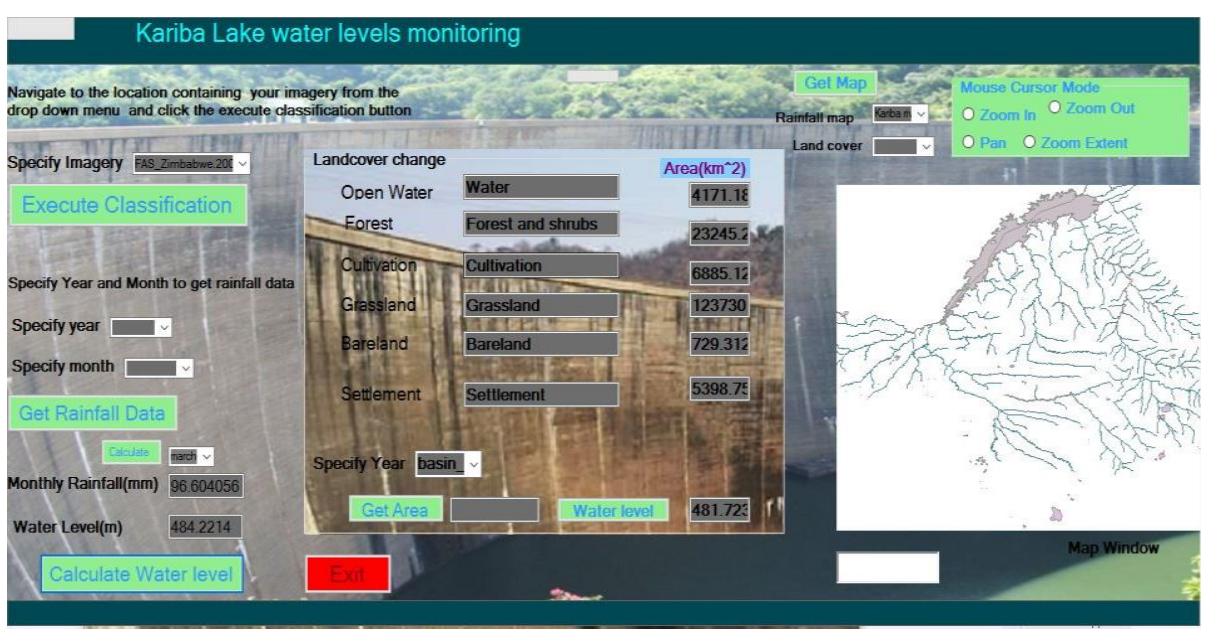

Fig. 4. Application highlighting Land use/cover output area results for 2005 satellite imagery and representation of Kariba lake with its tributary rivers

\section{Conclusions}


The study's objective was to a remote sensing and GIS based application for monitoring water levels at Kariba dam. Four conclusions can be drawn;

1) The mapping of the Kariba lake shore line extent was effectively carried out and a general decrease in surface area of about 4\% from 1973 to 2015 . The variation of the surface area of the Lake Kariba being mainly affected by the rainfall distribution patterns in the basin as highlighted by the positive correlation between the two variables.

2) From the supervised classification carried out on Landsat and MODIS imagery, a general decrease in forest and shrubs, grassland and open water was observed from 1973 to 2015. An increase in agricultural land and Bare-land was also observed. One explanation which can be derived from the changes is the conversion of forests and grassland to agriculture as a result of the escalating population in the Zambezi basin. Clearing of land for agriculture, logging industry and increase in siltation levels in the lake were the major causes of these land cover/ use changes.

3) The results obtained from the statistical analysis indicated that of the anthropogenic factors, forest and grassland cover reduction within the basin were found to be the significant factors necessitating long term water level variations and power generation at Kariba. The results highlight a strong negative correlation between forest and shrubs and water levels $(\mathrm{R} 2=0.13, \mathrm{p}<0.05)$. A fairly strong negative relationship between grassland and water levels $(\mathrm{p}<0.05, \mathrm{R} 2=0.10)$. From the environmental factors, rainfall and evaporation had the most significant impact on water level and hydropower generation variations at Kariba dam. Rainfall accounted for $75 \%$ of the variation in water levels whilst evaporation accounts for $28 \%$ of water level losses. A positive correlation of 0.8 implies that rainfall is a major significant factor in predicting water levels. Rainfall also accounted for $80 \%$ of the hydropower variation. Abstraction volumes and outflows accounted for $7 \%$ of the variation in water levels.

4) This research also enabled the classification of satellite imagery to be automated by making use of the handshaking capabilities between remote sensing and GIS tools. Processing of satellite rainfall and evaporation data and extraction of information from the imagery was also automated. Rainfall data extracted from satellite imagery was found to be tallying with that measured from the Kariba Airport Meteorological station.

By making use of the continuous monitoring of rainfall data together with forest and grassland land cover changes, an application was designed to monitor the water levels at Kariba dam. Water level and electricity generated derived was found to be tallying with in-situ measured data during the same period at an accuracy of $95 \%$ and $93 \%$ respectively. 


\section{References}

[1] Abileah, R., Vignudelli, S.: A Completely Remote Sensing Approach To Monitoring Reservoirs Water Volume. Heron I, 59-72 (2011)

[2] Adams, W.: The physical geography of Africa (1996)

[3] Arnell, N.W.: Climate change and global water resources 99 (1999)

[4] Badwan, A.B.I.: GIS Based System for Evaluating Groundwater Quality in the Gaza (2010)

[5] Bank, W.: Shared watercourses in the Southern african (2002)

[6] Beekman, H.E., Saayman, I., Hughes, S.: Vulnerability of Water Resources to Environmental Change in Southern Africa (2003)

[7] Beilfuss, R. : Land Use Change and Human Impacts. Zambezi basin Wetl. III, 31 (2000)

[8] Beilfuss, R..: A Risky Climate for Southern African Hydro assessing hydrological risks and A Risky Climate for Southern African Hydro(2012)

[9] Bertinelli, L., Strobl, E.: Trends in rainfall and economic growth in africa : a neglected cause of the african growth tragedy, 350-366 (2016)

[10] Cole, M.: The Kariba project.45, 98-105(2016)

[11] Dalal-clayton, B.: Southern africa beyond the millenium : environmental trends and scenarios to 2015 (2015)

[12] David, E.N.G.M.: Zimbabwe energy situation report (2015)

[13] Desanker, P.: Impact of climate change on Africa, 1-7 (2002)

[14] Eamus, D.: Catchment water balance, climate and groundwater (1998)

[15] Engineering Institution of Zambia.: Report on zesco load shedding engineering institution of Zambia (2015)

[16] Environment Agency: Managing water abstraction. Bristol Environmental Agency 29 (2013) 
[17] ESIA Zambezi River Authority, K.D.R.: 4 baseline information. Environ. Resour. Manag (2014)

[18] F.A.O: Adaptation to climate change in agriculture , forestry and fisheries : Perspective , framework and. Rome (2007)

[19] Gandolfi, C., Guariso, G., Togni, D.: Optimal Flow Allocation in the Zambezi River System 377-393 (1997

[20] Kunz, M.J.: Effect of Large Dams in the Zambezi River Basin : Changes in Sediment , Carbon and Nutrient Fluxes Effect of Large Dams in the Zambezi River Basin : Changes in Sediment , Carbon and Nutrient Fluxes (2011)

[21] Kusangaya, S., Warburton, M.L., Garderen, E.A. Van, Jewitt, G.P.W.: Impacts of Climate Change on Water Resources in Southern Africa: A Review 1-17 (2013)

[21] Macdonald, E.M.: Rapid Assessment - Final Report Integrated Water Resources Management (2007)

[22] Magadza, C.H.D.:. Kariba Reservoir Experience and Lessons Learned Brief 6 (2006)

[23] Malmer, A.: 5 Forest Cover and Global Water Governance 75-94 (2015)

[24] Malone, D.: NSW strategic water information and monitoring plan Final report (2009)

[26] Mbano, D., Chinseu, J., Ngongondo, C., Sambo, E., Mul, M.: Impacts of rainfall and forest cover change on runoff 9, 11-17 (2009)

[27] Mhlanga, L., Nyikahadzoi, K.: Fragmentation of Natural Resources Management (2013)

[28] Miyasaka, T., Okuro, T., Zhao, H., Zhao, X., Zuo, X., Takeuchi, K.,. Impacts of the local land-use system in a semi-arid region of northeastern China on soil properties, crop growth, and weed communities. J. Arid Environ. 75, 1155-1163. doi:10.1016/j.jaridenv.2011.06.009 (2011) [29] Muluneh, A.:. Synthesis of research on land use and land cover 1-39 (2010)

[30] Mustafa, Y.T., Noori, M.J.: Satellite remote sensing and geographic information systems (GIS) to assess changes in the water level in the Duhok dam. Int. J. Water Resour. Environ. Eng. 5, 351-359. doi:10.5897/IJWREE2012.0402 (2013)

[31] Muzein, B.S.: Remote Sensing \& GIS for Land Cover / Land Use Change Detection and Analysis in the Semi-Natural Ecosystems and Agriculture Landscapes of the Central Ethiopian Rift Valle (2006)

[32] Mwiinga, P: Implications of converting lake kariba to multipurpose dam in view of increased demand for water in Zambia and Zimbabwe. University of Zambia (2010)

[33] Office, U.S.D. of the I.B. of R.P.: Reclamation Managing Water in the West (2005)

[34] Omute, P., Corner, R., Langat, J.: The use of NDVI and its Derivatives for Monitoring Lake Victoria' s Water Level and Drought Conditions 1591-1613. doi:10.1007/s11269-0119974-z (2012)

[35] Oyinloye, R.O., Oloukoi, J.: An assessment of the Pull between Landuse and Landcover in Southwestern Nigeria and the Ensuing Environmental Impacts An assessment of the Pull between Landuse and Landcover in Southwestern Nigeria and the Ensuing Environmental Impacts 2013, 6-10 (2013)

[36] Pavelsky, T.M., Smith, L.C.: Remote sensing of suspended sediment concentration, flow velocity, and lake recharge in the Peace-Athabasca Delta , Canada 45, 1-16. doi:10.1029/2008WR007424 (2009)

[37] Phiri, M.: An analysis of the cahora bassa dam water balance and reservoir operations and their flooding impact. An Anal. Cabora Bassa Dam water Balanc. impact Reserv. Oper. settlements upstream. University of Zimbabwe (2011)

[38] Pribadi, A., Wongwises, P., Humphries, U., Limsakul, A., Wangwongchai, A.: Diurnal Rainfall Variation over Three Rainfall Regions within Indonesia Based on Ten Years of TRMM Data 3, 81-86 (2012) 
[39] Rawat, J.S., Kumar, M.: Monitoring land use/cover change using remote sensing and GIS techniques: A case study of Hawalbagh block, district Almora, Uttarakhand, India. Egypt. J. Remote Sens. Sp. Sci. 18, 77-84. doi:10.1016/j.ejrs.2015.02.002 (2015)

[40] Shaw, G.A., Burke, H.K.: Remote Sensing 14, 3-28 (2003)

[41] Soils Incorporated (Pty) Ltd, Chalo Environmental and Sustainable Development Consultants:. Kariba Dam: Zambia and Zimbabwe. Kariba Dam Zambia Zimbabwe (2000)

[42] Taimu, B.D.: A weed survey of the arable lands of small-scale farmers in Chimanimani district in Zimbabwe (2014)

[43] The National Academy of Sciences for United States of America:. Hydrologic Effects of a Changing Forest Landscape (2008)

[44] Timberlake, J.: Biodiversity of the Zambezi basin (2000)

[45] Unganai, L.S.: Historic and future climatic change in Zimbabwe 6, 137-145(1996)

[46] Usha, R., Kamalesh, S., Preethi, S., K, C.S.C., Suganya, C.: Web Based Service to Monitor Water Flow Level in Various Applications Using Sensors 2, 119-122 (2013)

[47] Vuglinsky, V. Water level. Water Lev. Lakes Reserv. storage (2009)

[48] Warburton, M.L.: Challenges in modelling hydrological responses to impacts and interactions of land use and climate change (2012)

[49] Wenbin\&Shaofeng, Z.: Monitoring the Fluctuation of Lake Qinghai using remote sensing data 10457-10482. doi:10.3390/rs61110457 (2014)

[50] Weng, Q.: Land use change analysis in the Zhujiang Delta of China using satellite remote sensing, GIS and stochastic modelling 273-284. doi:10.1006/jema.2001.0509 (2002)

[51] Yamba, F.D., Walimwipi, H., Mzezewa, C.: Climate change / variability implications on hydroelectricity generation in the Zambezi River Basin. Clim. Chang. / Var. Implic. 